\title{
Analysis of fungal contamination in subways of the metropolitan region of recife-pe, Brazil
}

\begin{abstract}
The daily population is exposed to contamination by various types of microorganisms. Fungi contamination may occur through indirect contact with inanimate objects and surfaces, including transportation, which, being colonized, begin to act as carriers of these microorganisms. The objective of this study was to evaluate the occurrence of fungus contamination in the subways of the metropolitan region of Recife-PE. The collections were carried out on three consecutive days in April 2018 in nine different subways using a sterile swab, obtaining five samples from each of the nine meters analyzed and sent to the laboratory of Medical Mycology Sylvio Campos of the Federal University of Pernambuco for analysis. A total of 45 samples were collected, of which 25 were positive for fungi, with one or more colony growing in each sample, six (24\%) of the Cajueiro Seco line, being nine $(36 \%)$ from the Jaboatao line and ten $(40 \%)$ from the Camaragibe line, totaling 38 fungal isolates. Five genus of fungi were identified: Aspergillus, Penicillium, Acremonium, Rhodotorula and yeasts of the genus Candida, the Aspergillus group niger was the species of higher occurrence. The region with the highest level of contamination was the window (24\%) followed by the bench and door $(21 \%)$. In view of the above, some precautionary measures could be taken to prevent fungal contamination of public transport surfaces, highlighting the hygiene of the areas that presented the greatest contamination and the realization of public awareness campaigns about the risks of acquiring infections upon contact with fungi.
\end{abstract}

Keywords: subway, microorganisms, fungi, contamination, infection
Volume 7 Issue 2 - 2019

\author{
Liliane Cristina da Silva,' Paulo Ricardo \\ Anjos do Monte,' Melyna Chaves Leite de \\ Andrade, ${ }^{3}$ Rejane Pereira Neves, ${ }^{3}$ Maria \\ Amelia Vieira Maciel, ${ }^{3}$ Jailton Lobo da Costa \\ Lima, ${ }^{3}$ Laury Francis Costa ${ }^{2}$ \\ 'Discente do Curso de Biomedicina do Centro Universitario \\ Mauricio de Nassau, Brazil \\ 2Doutora em Tecnologias Energeticas e Nucleares, Docente do \\ Centro Universitario Mauricio de Nassau, Brazil \\ ${ }^{3}$ Programa de Pos-graduacao em Medicina Tropical, Universidade \\ Federal de Pernambuco, Brazi
}

Correspondence: Jailton Lobo da Costa Lima, Programa de Pos-graduacao em Medicina Tropical, Universidade Federal de Pernambuco, Brazil, Email jailtonlobo@hotmail.com

Received: January 31, 2019 | Published: March 26, 2019

\section{Introduction}

The population is exposed daily to contamination due to contact with various microorganisms dispersed in nature and in objects. Although most of these microorganisms are non-pathogenic and do not cause damage to immunocompetent individuals, a small percentage may be responsible for several pathologies. ${ }^{2}$

Fungi, like bacteria, make up the microbiota of living beings, and can live in harmony with the host without causing disease. ${ }^{3}$ Thus, the equilibrium of the parasite-host relationship offers relevant benefits for humans, such as nutrient absorption, protection against invading pathogenic microorganisms, production of vitamins and contributing to the development of the immune system, as well as providing nutrients necessary for the survival of fungi. ${ }^{2-4}$

The unbalance of this relationship between the fungus and the host can contribute these pathogenic microorganisms opportunistic and may be harmful to immunocompromised individuals. It may also be influenced by factors associated with the age range (infants and elderly), nutritional status, chronic diseases (diabetes, cancer and autoimmune diseases), surgeries, stress, use of immunosuppressive drugs such as corticosteroids, chemotherapeutics and radiotherapy for reducing the effectiveness of the immune system. ${ }^{1-3,5}$ In addition, climatic factors, poor hygiene habits and poor housing increase the likelihood of these infections. ${ }^{4}$

Contamination of individuals by fungi can occur through indirect contact with inanimate objects (stethoscopes, mobile devices, helmets) and surfaces, including transportation (buses, subways and cars) that, when they are colonized, act as carriers of these microorganisms, thus being a potential source of fungal contamination. ${ }^{6-11}$
Studies have shown that collective transportation, such as the subway, because it is a closed transport and has a large circulation of people traveling 24 hours, has been considered a potential source of dissemination of microorganisms to its users. ${ }^{1-3,10}$ Fungi may be dispersed in the air (due to contamination of the air-conditioning system) or colonizing internal surfaces of the subway, such as: seats, handrails, windows and doors, which act as a means of propagating these microorganisms. ${ }^{1,2}$ Passenger contact with mold-contaminated sites and air can range from superficial fungal infections to systemic and opportunistic fungal infections.

Recent studies have shown that filamentous and yeast fungi have been found dispersed in the air and on subway surfaces. ${ }^{2}$ Some of these fungi can be considered as causing damage to humans and are responsible for triggering allergic processes, intoxications and infections. The fungus genera most found in studies that analyzed contamination in environments where: Cladosporium sp, Penicillium sp, Aspergillus sp, Mucor sp, Rhizopus sp, Candida sp, Alternaria sp, among others. ${ }^{2,4}$ In view of the above, the objective of this study was to evaluate the contamination caused by fungi in subways of the metropolitan region of Recife-PE.

\section{Methods}

\section{Sample collection and processing}

This is an experimental, descriptive research with a quantitative approach, carried out in the subways of the metropolitan region of Recife-PE, in the South (Cajueiro seco), Camaragibe and Jaboatao lines, to evaluate the occurrence of fungus contamination in the various surfaces of the subway also the fungal identification. 
The collections were carried out on three consecutive days in April 2018 , in nine different subways, three of them from the Camaragibe line, three from Jaboatao and three from dry Cajueiro. The collection sites were selected strategically, trying to determine the points of intense contact of the users and greater viability of contamination, such as high and low handrails, door, window and seats all touched superficially by users.

Sterile swab technique was used to collect samples. Each area was delimited by a quadrant with an area of 24 square Two being collected by means of superficial swabs, obtaining five samples from each of the nine subways analyzed. The swabs previously identified with the subway line code and the collection site were transported in a Styrofoam box and sent to the Medical Micology Laboratory Sylvio Campos of the Federal University of Pernambuco for analysis. The collected material was sown in streaks on the surface of the medium Sabouraud Agar Dextrose added with Chloramphenicol $(50 \mathrm{mg} / \mathrm{L})$ contained in Petri dishes. Subsequently, the plates were incubated at room temperature $\left( \pm 28^{\circ} \mathrm{C}\right)$ for a period of seven days for fungal development.

\section{Fungal identification}

Fungal identification was performed by analyzing macroscopic and micro morphological characteristics of fungal colonies by preparing slides containing fragments of cultures stained with Amam Blue.

\section{Results}

\section{Sample collection and processing}

A total of 45 swab samples were collected, of which 25 were positive for fungi, with one or more colony growing in each sample, six of the Cajueiro Seco line, nine of the Jaboatao line and 10 of the Camaragibe line Table 1, totaling 38 fungal isolates.

Table I Isolation of fungi in several regions of three subway lines of the metropolitan region of Recife-PE

\begin{tabular}{llll}
\hline \multirow{2}{*}{ Collection Regions } & Subway lines & & \\
\cline { 2 - 4 } & Cajueiro Seco I & Cajueiro Seco 2 & Cajueiro Seco 3 \\
\hline Window & + & - & - \\
Low Handrail & - & - & - \\
High Handrail & + & - & - \\
Door & - & + & + \\
Chair & - & + & + \\
\hline & Linha Jaboatão I & Linha Jaboatão 2 & Linha Jaboatão 3 \\
\hline Window & + & - & + \\
Low Handrail & - & + & + \\
High Handrail & + & + & + \\
Door & + & - & + \\
Chair & - & - & - \\
\hline & Linha Camaragibe I & Linha Camaragibe 2 & Linha Camaragibe 3 \\
\hline Window & - & + & + \\
Low Handrail & - & + & + \\
High Handrail & + & + & - \\
Door & + & - & + \\
Chair & + & + & + \\
\hline
\end{tabular}

Negative samples; +: Positive samples.

\section{Fungal identification}

Five genera of fungi were identified in this study: Aspergillus, Penicillium, Acremonium, Rhodotorula and yeasts of the genus
Candida Figure 1. Within the genus Aspergillus, it was possible to identify three species (Aspergillus Niger group, Aspergillus Group terrides, and Aspergillus restrictus), being the Aspergillus niger group the most frequent species Table 2.

Table 2 Fungi isolates found in different areas within the city subway of the Recife-PE

\begin{tabular}{lllllll}
\hline Fungical isolateds & Window & Low handrail & High handrail & Door & Chair & Total \\
\hline Penicillium sp. & $\mathrm{I}$ & - & $\mathrm{I}$ & $\mathrm{I}$ & $\mathrm{I}$ & 4 \\
Acremonium sp. & - & - & - & $\mathrm{I}$ & - & $\mathrm{I}$ \\
Aspergillus grupo niger & 8 & $\mathrm{I}$ & 5 & 6 & 5 & 25 \\
Aspergillus grupo terreus & - & 2 & - & - & - & 2 \\
Aspergillus restrictus & - & $\mathrm{I}$ & - & - & - & $\mathrm{I}$ \\
\hline
\end{tabular}


Table Continued....

\begin{tabular}{lllllll}
\hline Fungical isolateds & Window & Low handrail & High handrail & Door & Chair & Total \\
\hline Rhodotorula sp. & - & - & - & - & I & I \\
Candida sp. & - & 2 & 1 & - & 1 & 4 \\
\hline Total & 9 & 6 & 7 & 8 & 8 & 38 \\
\hline
\end{tabular}

Absence of fungal growth.

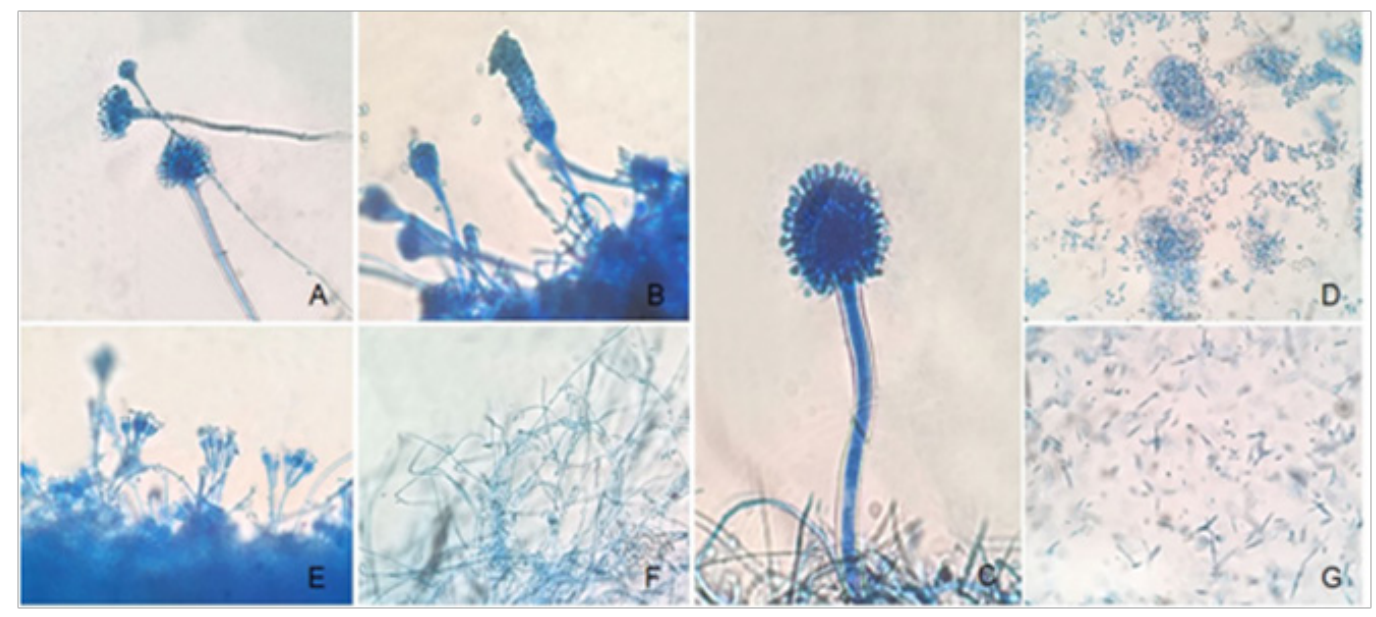

Figure I Micromorphology of fungi isolated from different regions of the subway lines of the city of Recife-PE: (A) Conidioforo de Aspergillus group terreus (B) Conidiophore of Aspergillus restrictus (C) Aspergillus conidiophore group niger (D) Yeasts of the genus Candida (E) Conidiophore of Penicillium sp (F) Acremonium sp. and (G) Rhodotorula.

The region with the highest level of contamination was the window (24\%) followed by the bench and door (21\% in both), high handrail $(18 \%)$ and finally low handrail $(16 \%)$.

\section{Discussion}

In the study analyzing microorganisms on a public transport bus route, used by the passengers, detected 37 fungal isolates in a roof loop and seats similar to the current study. ${ }^{2}$

Public environments, with intense circulation of people and various objects of common use, are places that serve as a reservoir of beneficial and pathogenic microorganisms. ${ }^{16}$ This fact has been proven in our study that, when analyzing underground lines, where there is intense movement of people, diverse filamentous fungi and yeast from the regions of the window, banisters, seats and doors were isolated.

A study in the city of Sao Paulo on handrails of 40buses, with a total of 120 samples, in which the main microorganisms isolated from bacteria were Candida spp. ${ }^{11}$ disagreement of the present study in which there was a higher prevalence of filamentous fungi, especially the Aspergillus Niger group.

Analyze the presence of microorganisms in collective transportation in the city of Juazeiro do Norte, Ceara, and detected the presence of filamentous fungi $(79 \%)$ and yeasts $(40 \%)$, as well as bacteria. ${ }^{2}$ However, fungal isolates were not identified.

All species found in this study are pathogenic and can cause infections ranging from cutaneous to systemic infections, depending on the immune status of the individuals. Aspergillus group Niger, the species most frequent in the study, can cause aspergillosis, endophthalmitis, endocarditis, and cutaneous infections, as well as Penicillium sp and Acremonium sp. ${ }^{12}$ Yeasts of the genus Candida can also cause superficial infections such as onychomycosis, invasive infections such as candidemia, ${ }^{14}$ whereas yeasts of the genus Rhodotorula cause invasive infections in immunosuppressed patients. ${ }^{15}$

Although there are no data on the occurrence of infectious diseases due to subway use, the microorganisms found in this study may become potential pathogens and may affect the individual who is immunologically debilitated.

\section{Conclusion}

The present research showed that the subways, used as collective transport of Recife-PE, can act as a reservoir of fungi. In view of the above, some precautionary measures could be taken to prevent fungal contamination of public transport surfaces. Among these measures, hygiene of areas with the greatest contamination and awareness campaigns about the risks of get infections when coming in contact with fungi.

\section{Acknowledgments}

None.

\section{Conflicts of interest}

The authors declare that there are no conflicts of interest.

\section{Funding}

This work was financed with own resources.

\section{References}

1. Fernandes AAL, Rangel CD, Sena CJC, et al. Diversidade de Bacterias, Fungos e Formas de Resistencia de Parasitos em Duas Rotas de Onibus do Transporte Coletivo da Grande Vitoria-ES. SAPIENTIA Faculdade Pio XII. 2012;(11):39-45. 
2. Cordeiro PMD, Leandro LMG, Vandesmet VCS, et al. Analise microbiologica de assentos e alca de teto em transportes coletivos da cidade Juazeiro do Norte, Ceara. Revista interfaces. 2017;69-74.

3. Gomes NCP, FerreiraLG, Lembo T. Analise da contaminacao bacteriologica do setor de parada de onibus municipais do terminal rodoviario de uma cidade do interior do Estado de Sao Paulo. $J$ Health Sci Inst. 2016;34(3):140-143.

4. Amorim AR, Junior MEM, Romao HCS, et al. Condicoes higienicosanitarias, tipos bacterianos e teste de susceptibilidade antimicrobiana em transporte publico de uma cidade do alto Paranaiba/MG-Brasil. Rev Psicol Saude e Debate. 2017;3(1):68-86.

5. Garcia CTP, Saleh DMFVB, Sasagawa SM, et al. Pesquisa de microorganismos em canetas esferograficas utilizadas por estudantes universitarios. Arq Med Hosp. 2012;57(1):6-10.

6. Chadi F, Gacia ACB, Carvalho GC, et al. Avaliacao dos procedimentos de higienizacão dos brinquedos infantis e das brinquedotecas nacionais. Revista da Universidade Vale do Rio Verde. 2014;12(2):296-305.

7. Santos JAD. Estetoscopio: instrumento de diagnostico e de propagacao microbiana?. Revista Saude e Pesquisa. 2015;8(3):577-584.

8. Ziehe JM, Fernandes RB, Macedo MRV, et al. Determinacao da contaminacao fungica do ar em Creches Publicas do Rio do Janeiro/RJ. Vigilancia Sanitaria em Debate. 2014;2(1):51-56.

9. Silva MMR, Gotardi AHB, Barros AAS, et al. Isolamento e identificacao de microrganismos presentes em superficies de teclados e mouses de uma universidade de tres lagoas, MS. EBSCO. 2014;6(3):83-90.
10. Miranda JV, Prado JC, Brandao RS, et al. Identificacao de microorganismos encontrados em escovas de dente dos academicos do curso de farmácia da faculdade montes belos. Revista Faculdade Montes Belos (FMB). 2015;8(1):1-9.

11. Mendonca RGM, Olival GS, Mimica LMJ, et al. Potencial infeccioso do transporte publico de passageiro da cidade de sao Paulo. Arquivos Medico dos Hospitais e Faculdade de Ciencias Medicas Santa Casa Sao Paulo. 2008;53(2).

12. De Hoog GS, Guarro J, Gene J, et al. Atlas of clinical fungi. Int Microbiol. $2001 ; 4: 51-52$.

13. Almondes AIV, Araujo JOP, Amaral LMS, et al. Fungal contamination and disinfection of dental chairs. Acta odontol Latinoam. 2016;29(3):225-229.

14. Murray PR, Rosserthal KS, Pfaller MA. Microbiologia medica. 6th ed. Rio de Janeiro Elserver. 2009;74;728-751.

15. Tsiodras S, Papageorgiou S, Meletiadis J, et al. Rhodotorula mucilaginosa associacted meningitis: A subacute entity with high mortality. Caser report and review. Med mycol case Rep.2014;6:46-50.

16. Gomes NCP, Ferreira LG, Iembo T. Analise da contaminacao bacteriologica do setor de parada de onibus municipais do terminal rodoviário de uma cidade do interior do Estado de Sao Paulo. Journal of the Health Sciences Institute. 2016;34(3):140-143. 